\title{
Peran Pajak Restoran Terhadap Penerimaan Daerah Administrasi Jakarta Timur
}

\author{
Dede Suleman \\ Universitas BSI JAKARTA \\ dede.dln@bsi.ac.id
}

(Suleman, 2019)Suleman, D. (2019). Peran Pajak Restoran Terhadap Penerimaan Daerah Administrasi Jakarta Timur. Moneter, 6(1), 7-12.

\begin{abstract}
one of the local taxes is restaurant tax. in this research, it will give a big picture of contributing restaurant tax to Jakarta Timuel's original revenue. Regional taxes are divided into three types, taxes levied by local governments, taxes collected based on national regulations, but income tariffs made by local governments. Restaurant tax is a service provided by payment, a service provided by a restaurant called service includes the sale of food and / or drinks consumed by the buyer, whether consumed at the service place or elsewhere. The subject of restaurant tax is an individual or entity that makes payments to restaurants or restaurants, cafes, bars and the like, while taxpayers are individuals or entities that run restaurants. The restaurant tax rate set is $10 \%$. restaurant tax revenue increases every year and can exceed the target set only in 2014 restaurant tax revenue is only $82 \%$. restaurant tax contribution increases every year for East Jakarta administrative city tax revenues, which has a significant influence in 2014 amounting to $46.78 \%$ and 2015 at 50.19\% and 2016 at 55.69\%
\end{abstract}

Keywords: Restaurant Tax, Local Income

\section{PENDAHULUAN}

Perkembangan industri kuliner saat ini sangat pesat dan merupakan fenomena dimana berbagai sajian makanan mulai di hadirkan dengan konsep dan nuansa yang berbeda. Berbagai merk baik yang local maupun asing dari yang milik pribadi atau waralaba terus melebarkan sayap usahanya dan membuka cabang-cabang baru di tiap sudut jalan yang memiliki potensi pelanggan.

Hal ini memicu pada pertumbuhan jumlah restoran yang beroperasi di khusus nya di area Jakarta Timur yang merupakan satu kawasan bagian dari DKI Jakarta.yang memiliki motto bambu apus - sri dunting

Pajak di DKI Jakarta sendiri di kelola oleh Suku Badan Pajak dan Retribusi Daerah (BPRD) yang dulunya namanya Dinas Pelayanan paja (DPP). BPRD saat ini memiliki lima suku badan di lima wilayan DKI Jakarta antara lain :

a. BPRD kota Administrasi Jakarta Pusat

b. BPRD kota Administrasi Jakarta Barat

c. BPRD kota Administrasi Jakarta Utara dan Kabupaten kepulauan seribu

d. BPRD kota Administrasi Jakarta Selatan

e. BPRD kota Administrasi Jakarta Timur

Sedangkan masing-masing BPRD di kota Adminstrasi memiliki Unit Pelayanan Pajak dan Restribusi Daerah (UPPRD). Dan di kota administrasi Jakarta Timur sendiri memilli sepuluh UPPRD ditiap kecamatan diwilayahnya.
Ditiap UPPRD memiliki tugas melayani pemungutan jenis pajak dan pelaporan pajak antara lain :

a. Pajak PBB-P2

b. BPHTB

c. Reklame

d. Pajak Air Bawah Tanah (PABT)

e. Pajak Hotel

f. Pajak Restoran

g. Pajak Parkir

h. Pajak Hiburan

i. Pajak Bahan Bakar Kendaraan Bermotor (PBBKB)

Disamping itu UPPRD selaian menerima setoran pajak juga melayani mulai dari penilaian, pemeriksaan dan pengawasan, penetapan dan penagihan, pengurangan, keberatan dan banding untuk semua jenis pajak yang ada di wilayahnya .

Kota Administrasi Jakarta Timur memiliki luas kurang lebih $188 \mathrm{~km}^{2}$ jika di bandingkan dengan luas DKI Jakarta yang kurang lebih $661.5 \mathrm{~km}^{2}$, maka luas kota Adminstrasi Jakarta Timur ini sekitar $28.5 \%$ dari luas wilayah DKI Jakarta. Dengan area yang cukup luas ini maka penulis akan melihat berapa potensi yang dan kontribusi yang diberikan terhadap PAD DKI Jakarta untuk pajak Restoran di wilayah kota Admininstrasi Jakarta Timur itu sendiri.

Pajak restoran dapat digolongkan sebagai pajak tidak langsung, dimana pajak yang pengenaannya berdasarkan atas pelayanan yang diberikan kepada konsumen ini, bebannya berada pada konsumen. Dalam hal ini, pemilik atau pengusaha restoran merupakan pihak yang melakukan pemungutan dan 
menyetorkan hasil pajak tersebut kepada instansi yang berwenang menerima pengumpulan hasil pajak tersebut (suleman, 2017).

Pajak daerah juga merupakan salah satu sumber Anggaran Pendapatan dan Belanja Daerah (APBD) yang digunakan pemerintah untuk menjalankan program-programnya. Pemungutan pajak dapat bersifat dipaksakan karena sudah diatur dan sesuai dengan peraturan Perundang-undangan yang berlaku (Suleman, 2018)

\section{Pengertian Pajak}

Pajak adalah iuran kepada negara (yang dapat dipaksakan) yang terutang oleh yang wajib membayarnya menurut peraturan-peraturan, dengan tidak mendapatkan prestasi kembali, yang langsung dapat ditunjuk, dan yang gunanya adalah untuk membiayai pengeluaran-pengeluaran umum berhubungan dengan tugas negara yang menyelenggarakan pemerintahan (waluyo dalam (Suleman, 2018)

Pajak adalah iuran kepada kas Negara berdasarkan undang-undang (yang dapat dipaksakan) dengan tiada mendapatkan jasa timbal (kontraprestasi) yang langsung dapat ditunjukan dan yang digunakan untuk membayar pengeluaran umum menurut (Masdiasmo, 2011)

Definisi pajak menurut undang-undang nomor no 6 tahun 1983 tentang ketentuan umum dan tata cara perpajakan sebagaimana telah diubah terakhir dengan Undang-Undang Republik Indonesia Nomor 28 pasal 1 tahun 2007 menjelaskan bahwa : "pajak adalah kontribusi wajib kepada Negara yang terutang oleh orang pribadi atau badan yang bersifat memaksa berdasarkan Undang-Undang. Dengan tidak mendapatkan imbal balik secara langsung dan digunakan untuk keperluan Negara untuk sebesarbesarnya kemakmuran rakyat “

Menurut (Resmi, 2014) ciri-ciri pajak yang melekat pada definisi pajak :

a. Pajak dipungut berdasarkan atau dengan kekuatan undang-undang serta aturan pelaksanannya

b. Dalam pembayaran pajak tidak dapat ditunjukan adanya kontraprestasi undividual oleh pemerintah.

c. Pajak di pungut oleh Negara, baik pemerintah pusat maupun pemerintah daerah.

d. Pajak diperuntukan bagi pengeluaranpengeluaran pemerintah yang bila dari pemasukannya masih dapat surplus, digunakan untuk membiayan public investment.

Fungsi pajak menurut (Diana, 2013) memiliki dua fungsi utama, diantaranya :

a. Fungsi penerimaan (budgeter) b. Yaitu sebagai alat (sumber untuk memasukan uang sebanyak-banyaknya dalam kas Negara dengan tujuan membiayai pengeluaran Negara yaitu pengeluaran rutin dan pembangunan. Sebagai sumber pendapatan Negara pajak berfungsi untuk membiayai pengeluaranpengeluaran Negara.

c. Fungsi Mengatur (regulerend)

d. Sebagai fungsi alat untuk mencapai tujuan tertentu dibidang keuangan (bidang ekonomi, politik,budaya,pertahanan keamanan).

\section{Pengertian Pajak Daerah}

Pajak daerah adalah selanjutnya disebut pajak, adalah kontribusi wajib keapada daerah yang terutang oleh pribadi atau badan yang bersifat memaksa berdasarkan Undang-Undang, dengan tidak mendapatkan imbalan secara langsung dan digunakan untuk keperluan daerah bagi sebesar-besarnya kemakmuran rayat (Mardiasmo, 2016)

Pajak adalah iuran kepada negara (yang dapat dipaksakan) yang terutang oleh yang wajib membayarnya menurut peraturan-peraturan, dengan tidak mendapatkan prestasi kembali, yang langsung dapat ditunjuk, dan yang gunanya adalah untuk membiayai pengeluaran - pengeluaran umum berhubungan dengan tugas negara yang menyelenggarakan pemerintahan. (waluyo , 2011).

Menurut undang-undang No.33 tahun 2004 pasal 6, sumber-sumber pendapatan asli daerah terdiri dari:

a. Pajak daerah Pajak daerah adalah iuran wajib yang dilakukan oleh orang pribadi atau badan kepada daerah tanpa imbalan langsung yang seimbang yang dapat dipaksakan berdasarkan peraturan perundang-undangan yang berlaku dan yang digunakan untuk membiayai penyelenggaraan pemerintah daerah dan pembangunan daerah. Pajak merupakan sumber keuangan pokok bagi daerah-daerah restribusi daerah.

b. Retribusi daerah retribusi daerah adalah pungutan daerah sebagai pembayaran atas jasa atau pemberian izin tertentu yang khusus disediakan dan atau diberikan oleh pemerintah daerah untuk kepentingan orang pribadi atau badan.

c. Hasil pengelolaan kekayaan daerah yang dipisahkan hasil pengelolaan kekayaan milik daerah yang dipisahkan merupakan penerimaan daerah yang berasal dari pengelolaan kekayaan daerah yang dipisahkan. Jenis pendapatan ini dirinci menurut objek pendapatan yang mencakup

1) Bagian laba atas penyertaan modal pada perusahaan milik daerah atau BUMD.

2) Bagian laba atas penyertaan modal pada perusahaan milik Negara atau BUMN.

3) Bagian laba atas penyertaan modal pada perusahaan milik swasta atau kelompok. 
d. Lain-lain pendapatan yang sah pendapatan ini merupakan penerimaan daerah yang berasal dari lain-lain milik pemerintah daerah. Rekening ini disediakan untuk mengakuntansikan penerimaan daerah selain yang disebut diatas. Jenis sebagai berikut :

1) Hasil penjualan asset daerah yang tidak dipisahkan.

2) Jasa giro.

3) Pendapatan bunga.

4) Penerimaan atas tuntutan ganti kerugian daerah.

5) Penerimaan komisi, potongan, ataupun bentuk lain sebagai akibat dari penjualan, pengadaan barang dan jasa oleh daerah.

6) Penerimaan keuangan dari selisih nilai tukar rupiah terhadap mata uang asing.

7) Pendapatan denda atas keterlambatan pelaksanaan pekerjaan.

8) Pendapatan denda pajak.

9) Pendapatan denda retribusi.

10) Pendapatan eksekusi atas jaminan.

11) Pendapatan dari pengembalian.

12) Fasilitas sosial dan umum.

13) Pendapatan dari penyelenggaraan pendidikan dan pelatihan.

14) Pendapatan dari anggaran atau cicilan penjualan.

Hukum pajak pemungutan pajak Daerah di DKI Jakarta adalah Sebagai berikut :

Tabel 1. Dasar Hukum Pajak DKI Jakarta

\begin{tabular}{|c|c|c|c|}
\hline No & Jenis Pajak & $\begin{array}{c}\text { Peraturan } \\
\text { Daerah }\end{array}$ & Tarif \\
\hline 1 & $\begin{array}{l}\text { Pajak Kendaraan } \\
\text { Bermotor }\end{array}$ & $\begin{array}{c}\text { Nomor } 2 \\
\text { Tahun } \\
2015\end{array}$ & $2 \%-10 \%$ \\
\hline 2 & $\begin{array}{l}\text { Bea Balik Nama } \\
\text { Kendaraan Bermotor }\end{array}$ & $\begin{array}{c}\text { Nomor } 9 \\
\text { Tahun } \\
2010\end{array}$ & $\begin{array}{l}0.75 \%-10 \% \\
(\mathrm{BBN} 1) \\
0.075 \%-1 \% \\
(\mathrm{BBN} \text { II) }\end{array}$ \\
\hline 3 & $\begin{array}{l}\text { Pajak bahan Bakar } \\
\text { Kendaraan bermotor }\end{array}$ & $\begin{array}{c}\text { Nomor } \\
10 \text { Tahun } \\
2010\end{array}$ & $5 \%$ \\
\hline 4 & Pajak Hotel & $\begin{array}{l}\text { Nomor } \\
11 \text { Tahun } \\
2010\end{array}$ & $10 \%$ \\
\hline 5 & Pajak Hiburan & $\begin{array}{c}\text { Nomor } 3 \\
\text { Tahun } \\
2015\end{array}$ & $5 \%-35 \%$ \\
\hline 6 & $\begin{array}{l}\text { Pajak Penerangan } \\
\text { Jalan }\end{array}$ & $\begin{array}{l}\text { Nomor } \\
15 \text { Tahun } \\
2010\end{array}$ & $1.5 \%-3 \%$ \\
\hline 7 & Pajak Air Tanah & $\begin{array}{c}\text { Nomor } \\
17 \text { Tahun } \\
2010\end{array}$ & $20 \%$ \\
\hline 8 & Pajak Parkir & $\begin{array}{c}\text { Nomor } \\
16 \text { Tahun } \\
2010\end{array}$ & $20 \%$ \\
\hline 9 & ВРНТВ & $\begin{array}{c}\text { Nomor } \\
18 \text { Tahun } \\
2010\end{array}$ & $5 \%$ \\
\hline
\end{tabular}

\begin{tabular}{clcc}
10 & Pajak Restoran & Nomor & $10 \%$ \\
& & 11 Tahun & \\
& & 2011 & \\
11 & Pajak Reklame & Nomor & $25 \%$ \\
& & 12 Tahun & \\
& & 2011 & \\
12 & PBB pedesaan dan & Nomor & $0.01 \%-0.3 \%$ \\
& kota & 16 Tahun \\
& & 2011 & \\
13 & Pajak Rokok & Nomor 2 & $10 \%$ \\
& & Tahun & \\
& & 2014 & \\
\hline
\end{tabular}

Sumber: Badan Pajak dan Retribusi Daerah DKI Jakarta

\section{Pendapatan Asli Daerah}

mengemukakan bahwa Pendapatan Asli Daerah (PAD) adalah penerimaan yang diperoleh daerah dari sumber-sumber dalam wilayahnya sendiri yang dipungut berdasarkan peraturan daerah sesuai dengan peraturan perundang-undangan yang berlaku. (Siahaan, 2010).

Pemerintah daerah diharapkan lebih mampu menggali sumber-sumber keuangan secara maksimal, namun tentu saja dalam koridor perundang-ungangan yang berlaku khususnya untuk memenuhi kebutuhan pembiayaan pemerintah dan pembangunan didaerahnya melalui pendapatan asli daerah. Tuntutan peningkatan PAD semakin besar seiring dengan semakin banyakanya kewenagan pemerintah yang dilimpahkan kepada daerah itu sendiri.

\section{Pajak Restoran}

Pajak restoran dapat digolongkan pajak tidak langsung, dimana pahak yang pengenaannya berdasarkan atas pelayanan yang di berikan kepada konsumen ini, bebabnya berapa pada konsumen. Dalam hal ini pemilik atau pengusaha restoran merupakan pihak yang melakukan pemungutan dan menyetorkan hasil pajak tersebut kepada instansi yang berwenang menerima pengumpulan hasil pajak tersebut. (suleman, 2017)

Menurut perda Nomor 11 tahun 2011 adalah pajak atas pelayanan yang disediakan oleh restoran. Sedangkan pengertian restoran adalah fasilitas penyedia makanan dan/atau minuman dengan dipungut bayaran, yang mencakup juga rumah makan, kafetaria, kantin,warung, bar dan sejenisnya termasuk jasa boga/katering.

Dalam pemungutan pajak Restoran terdapat beberapa terminologi yang perlu di ketahui, terminology tersebut menurut peraturan daerah no.11 Tahun 2011 dapat dilihat sebagai berikut

a. Restoran adalah tempat menyantap makanan dan/atau minuman yang disediakan dengan dipungut bayaran yang mencakup rumah makan, kafetaria, kantin, warung, bar dan sejenisnya termasuk jasa boga dan catering.

b. Pengusaha restoran adalah orang pribadi atau badan dalam bentuk apapun, yang dalam 
lingkungan perusahaan atau pekerjaan melakukan usaha dibidang rumah makan.

c. Pembayaran adalah jumlah yang diterima atau seharusnya diterima sebagai imbalan atas penyerahan barang atau pelayanan, sebagai pembayaran atas pemilik rumah makan.

d. Bon penjual (bill) adalah bukti pembayaran, yang sekaligus sebagai bukti pungutan pajak, yang dibuat oleh wajib pajak pada saat mengajukan pembayaran atas pembelian makanan atau minuman kepada subjek pajak.

Subjek pajak restoran sesuai perda Nomor 11 tahun 2011 adalah orang pribadi atau badan yang membeli makanan dan/atau minuman dari restoran.

Objek pajak restoran itu sesuai perda nomor 11 tahun 2011 adalah :

a. Objek pajak adalah pelayanan yang disediakan oleh restoran

b. Pelayanan yang disediakan restoran sebagaimana dimaksud meliputi pelayanan penjualan makanan dan atau minuman yang di konsumsi oleh pembeli, baik dikonsumsi ditempat ataupun di tempat lain.

Ada beberapa pengecualian dalam pajak restoran antara lain :

a. Pelayanan yang disediakan restoran atau rumah makan yang pengelolannya satu manajemen dengan hotel

b. Pelayanan yang disediakan restoran yang nilai penjualannya (peredaran usaha) tidak melebihin Rp. 200.000.000,-(dua ratus juta rupiah) per tahun.

\section{Dasar Pengenaan, Tarif dan Cara Perhitungan}

Menurut Undang-Undang Nomor 28 Tahun 2009 pasal 40 paling tinggi ditentukan sebesar sepuluh persen dan ditetapkan dengan peraturan Daerah kabupaten atau kota yang bersangkutan. hal ini dimaksudkan untuk memberikan keleluasaan kepada pemerintah kabupaten/kota untuk menetapkan tarif pajak restoran yang dipandang sesuai dengan kondisi kabupaten/kota masing-masing.

Dasar pengenaan pajak restoran menurut perda No 11 tahun 2011 adalah jumlah pembayaran yang di lakukan kepada restoran berlaku juga untuk pelayanan kepada instansi pemerintahan.

Besaran pokok Pajak Restoran yang terutang dihitung dengan cara mengalikan tarif pajak dengan dasar pengenaan pajak. Secara umum perhitungan pajak restoran adalah sesuai perhitungan berikut (Siahaan, 2010)

Pajak Terutang $=$ Tarif Pajak $\mathrm{x}$ Dasar Pengenaan Pajak $=$ Tarif Pajak $\mathrm{x}$ Jumlah pembayaran diterima atau yang seharusnya diterima Restoran

Menurut Pergub nomor 22 Tahun 2007 pemungutan pajak restoran tidak dapat diborongkan artinya seluruh proses pemungutan pajak restoran tidak dapat diserahkan kepada pihak ketiga. Setiap pengusaha restoran wajib memperhitungkan, membayarkan dan melaporkan sendiri pajak restoran yang terutang dengan menggunakan Surat Pemberitahuna Terutang Pajak Daerah (SPTPD). Artinya fiskus hanya bertugas mengawasi pelaksanaan pemenuhan kewajiban pajak oleh wajib pajak restoran.

Menurut (Siahaan, 2010) masa pajak merupakan jangka waktu yang lamanya sama dengan satu bulan takwin atau jangka waktu lain yang ditetapkan dengan keputusan bupati/walikota. Dalam pengertian masa pajak bagian dalam bulan dihitung satu bulan penuh. Tahun pajak adalah jangk waktu yang lamanya satu tahun takwin, kecuali Wajib Pajak menggunakan tahun buku yang tidak sama dengan tahun takwim.

Menurut Pergub No.22 tahun 2007 pajak pasal 9 tentang petunjuk pemungutan pajak restoran, pembayaran masa pajak restoran terutang dilakukan paling lambat 15 (lima belas) hari setelah berakhirnya masa pajak dengan menggunakan Surat Setoran Pajak Daerah (SSPD). Jika ada keterlambatan dikenakan sanksi bungan sebesar 2\% (dua persen) sebulan untuk jangka waktu paling lama 24 (dua puluh empat) bulan dan ditagih dengan STPD.

Menurut Pergub DKI Jakarta Nomor 22 Tahun 2007 pasal 22 dan pasal 24 wajib pajak restoran dengan peredaran usaha atau omset lebih dari Rp.300.000.000,(tiga ratus juta rupiah) dalam 1 (satu) tahun, wajib menyelenggarakan pembukuan sesuai dengan standard akuntansi keuangan Indonesia atau prinsip pembukuan secara umum. Dan pembukuan serta dokumen lain yang berkaitan dengan kegiatan usaha Wajib Pajak harus disimpan selama 5 (lima) tahun.

\section{METODOLOGI PENELITIAN}

Obyek penelitian adalah Kota Administrasi Jakarta Timur, Metode penelitian ini menggunakan metode perbandingan serta studi pustaka yang bersumber dari sejumlah literatur yang meliputi referensi buku-buku yang dapat menunjang isi penulisan, kemudian sejumlah situs internet yang dapat menambah wahana keilmuan sebagai penunjang topik pembahasan. Data yang diolah adalah tahun 2014, 2015 dan 2016.

\section{HASIL DAN PEMBAHASAN}

Hasil pembahasan akan diterangkan perbandingan data dari tahun ke tahun untuk pajak restoran di kota administrasi Jakarta Timur

\section{Perbandingan Target dan Realiasasi}

Data mengenai rekapan penerimaan peranan pajak asli daerah dan pendapatan asli daerah dinas pendapatan Kabupaten Bogor tahun 2014 sampai dengan tahun 2016 adalah sebagai berikut: 
Tabel 2 Target dan Realisasi

\begin{tabular}{cccc}
\hline Tahun & $\begin{array}{c}\text { Target } \\
(\mathrm{Rp})\end{array}$ & $\begin{array}{c}\text { Realisasi } \\
(\mathrm{Rp})\end{array}$ & $\begin{array}{l}\text { Prosenta } \\
\text { se }\end{array}$ \\
\hline 2014 & 111.000 .000 .000 & 90.010 .667 .348 & $82 \%$ \\
2015 & 119.385 .000 .000 & 120.367 .066 .166 & $101 \%$ \\
& & & $105 \%$ \\
\hline Sumber: Badan Pajak dan Retribusi Daerah DKI Jakarta
\end{tabular}

Dapat Disimpulkan dari Tabel 2 bahwa target Pajak Restoran tiap tahun mengalami kenaikan. Namun demikian untuk wilayah kota Administrasi Jakarta Timur untuk penerimaan pajak restoran selalu dapat mencapai target yang telah ditetapkan.

Pada tahun 2014 Target terhadap penerimaan pajak restoran tidak mencapai target didapati bahwa hanya sanggup mencapai $92 \%$ dari target yang di tetapkan.

$$
\begin{aligned}
& \text { prosentase }=\frac{\text { Realisasi }}{\text { Target }} \times 100 \% \\
& =\frac{\text { Rp. } 90.010 .667 .348}{\text { Rp. } 111.000 .000 .000} \times 100 \%=82 \%
\end{aligned}
$$

Pada tahun 2015 Target terhadap penerimaan pajak restoran dapat mencapai target dan melebihi target yang telah ditetapkan dan mencapai $101 \% \%$ dari target yang di tetapkan.

$$
\begin{aligned}
& \text { prosentase }=\frac{\text { Realisasi }}{\text { Target }} \times 100 \% \\
& =\frac{\text { Rp. } 120.367 .066 .166}{\text { Rp. } 119.385 .000 .000} \times 100 \%=101 \%
\end{aligned}
$$

Pada tahun 2016 Target terhadap penerimaan pajak restoran dapat mencapai target dan melebihi target yang telah ditetapkan dan mencapai $105 \% \%$ dari target yang di tetapkan.

$$
\begin{aligned}
& \text { prosentase }=\frac{\text { Realisasi }}{\text { Target }} \times 100 \% \\
& =\frac{\text { Rp. } 156.577 .884 .159}{\text { Rp. } 149.195 .000 .000} \times 100 \%=105 \%
\end{aligned}
$$

Tabel 3 Realisasi dan PAD Jakarta Timur

\begin{tabular}{cccc}
\hline Tahun & $\begin{array}{c}\text { Penerimaan } \\
(\mathrm{Rp})\end{array}$ & $\begin{array}{c}\text { PAD } \\
(\mathrm{Rp})\end{array}$ & $\begin{array}{l}\text { Prosenta } \\
\text { se }\end{array}$ \\
\hline 2014 & 90.010 .667 .348 & 194.325 .021 .946 & $46.78 \%$ \\
2015 & 120.367 .066 .166 & 239.776 .722 .633 & $50.19 \%$ \\
2016 & 156.577 .884 .159 & 281.115 .092 .896 & $55.69 \%$ \\
\hline
\end{tabular}

Sumber: Badan Pajak dan Retribusi Daerah DKI Jakarta

Berdasarkan tabel tersebut terlihat bahwa presentase penerimaan pajak restoran terhadap pendapatan asli daerah mengalami kenaikan setiap tahunnya.

Pada tahun 2014, persentase penerimaan Pajak Restoran terhadap Pendapatan Asli Daerah pada Kota Adminstrasi Jakarta Timur sebesar $46.78 \%$ didapat dari rumus:

$$
\begin{aligned}
& \text { Tahun } 2014=\frac{\text { pajak Restoran }}{\text { PendapatAsli Daerah }} \times 100 \% \\
& =\frac{\text { Rp } 90.010 .667 .348}{\text { Rp. } 194.325 .021 .946} \times 100 \%=46.78 \%
\end{aligned}
$$

Pada tahun 2015, persentase penerimaan Pajak Restoran terhadap Pendapatan Asli Daerah pada Kota Adminstrasi Jakarta Timur sebesar 50.19\% didapat dari rumus:

$$
\begin{aligned}
\text { Tahun } & 2015=\frac{\text { pajak Restoran }}{\text { PendapatAsli Daerah }} \times 100 \% \\
= & \frac{\text { Rp. } 120.367 .066 .166}{\text { Rp. } 239.776 .722 .633} \times 100 \%=50.19 \%
\end{aligned}
$$

Pada tahun 2016, persentase penerimaan Pajak Restoran terhadap Pendapatan Asli Daerah pada Kota Adminstrasi Jakarta Timur sebesar 55.69\% didapat dari rumus:

$$
\begin{array}{r}
\text { Tahun } 2016=\frac{\text { pajak Restoran }}{\text { PendapatAsli Daerah }} \times 100 \% \\
=\frac{\text { Rp. } 156.577 .884 .159}{\text { Rp. } 281.115 .092 .896} \times 100 \%=55.69 \%
\end{array}
$$

\section{KESIMPULAN}

Penerimaan pajak restoran tiap tahun mengalami kenaikan dan rata-rata kecendrungan nya dapat mencapai target dan melebihi dari target tiap tahun kecuali pada tahun 2014 yang pencapaiannya hanya sebesar $82 \%$

Bahwa ternyata untuk Kota Administrasi Jakarta Timur pajak restoran merupakan salah satu penerimaan pajak terbesar untuk Penerimaan Asli daerah diJakarta timur ini di buktikan bahwa pajak restoran prosentasenya hampir mencapai $50 \%$ dari penerimaan pajak daerah

\section{REFERENSI}

Diana. (2013). Konsep dasar perpajakan. Bandung: refika aditama.

Ichsan. (2013, November). Sistem Pendukung Keputusan Pemilihan Penerima Beasiswa Mahasiswa Kurang Mampu Pada STMIK BUDIDARMA Medan Menerapkan Metode Profile Matching. Kursor, 5(1), 2.

Mardiasmo. (2016). Perpajakan (XVIII). Yogyakarta: Andi Offset.

Masdiasmo. (2011). Perpajakan Edisi Revisi. Yogyakarta: andi offset.

Resmi, s. (2014). Perpajakan Teori dan Kasus. Jakarta: Salemba Empat.

sabil. (2017). Peranan penerimaan pajak reklamet terhadap pendapatan asli daerah pada 
kabupaten bogor jawa barat. Jurnal Moneter.

Siahaan, M. (2010). Pajak Daerah dan Retribusi Daerah. Jakarta: PT.Rajagrafindo Persada.

Siahaan, M. P. (2010). Pajak Daerah dan Retribusi Daera. Jakarta: PT.Rajagrafindo Persada.

suleman, d. (2017). Kontribusi Pajak Restoran Terhadap Pendapatan Asli Daerah. Jurnal Moneter, Vol. IV No. 2 Oktober pp 139-144.

Suleman, D. (2018). Kontribusi Pajak Hotel Terhadap (PAD) Dispenda Kabupaten Bogor. Jurnal Moneter, Vol. V No. 1 April pp 58-62.

Suleman, D. (2018). Kontribusi Pemungutan Bea Perolehan Hak atas Tanah dan Bangunan (BPHTB) Terhadap Pendapatan Asli Daerah (PAD). Moneter, 5(2), 1-6.

waluyo , P. (2011). Perpajakan Indonesia Edisi 10 buku 1. Jakarta: Salemba Empat.

\section{PROFIL PENULIS}

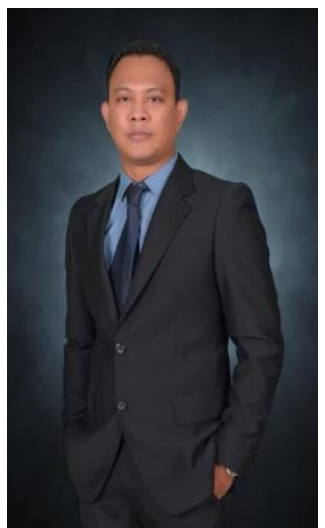

Dede Suleman adalah Doktor candidate Marketing di Universitas Mercubuana, Jakarta. Gelar Sarjana dari Universitas Azzahra, jurusan Ekonomi, dan Magister dari Universitas BSI Bandung.

Dede suleman saat ini sebagai pemilik dan sebagai pengelola di industri Restoran dengan sistem waralaba dengan merek My Bento yang telah dikembangkan selama 10 tahun, Dan juga berkarier sebagai Dosen tetap di Universitas Bina Sarana Informatika Jakarta Minat penelitiannya termasuk pengembangan dunia operasional waralaba dan manajemen waralaba, pemasaran dan perilaku konsumen serta perpajakan, keuangan, e-business, emarketing dan e-commerce 